\title{
Issues Relating to the Creation of a Central Database to Support Statistical Property Valuations*
}

\author{
Gabriella Grosz - Evelyn Herbert - Gábor Izsák - Katinka Szász
}

The valuation of real estate collateral is a long-established area of the lending process that is currently undergoing increasingly dynamic development and in which the use of statistical valuation methods is becoming more and more common instead of on-site valuations. The legal conditions for this have been created by amendments to European and national legislation in the past year, but for the method to be truly widely used and operational and to ensure the accuracy of the resulting valuations, access to detailed, accurate, up-to-date and regularly checked data on real estate must be also created. As the databases currently available for Hungarian real estate are very fragmented, in our study, we propose to create a central database that would provide a uniform, up-to-date set of data, by harmonising the existing separate databases. Such a database would help create a level playing field in the market and automate data transfer in a cost-effective, fast and reliable manner. This would greatly facilitate the uptake of statistical valuation methods, supporting the further spread of digitalisation, increasing banking competition, speeding up administration and reducing the cost of lending for all parties.

Journal of Economic Literature (JEL) codes: G21, G28, G32, G51, O33

Keywords: automation, digitalisation, collateral valuation, mortgage lending, financial regulation, statistical valuation

\footnotetext{
* The papers in this issue contain the views of the authors which are not necessarily the same as the official views of the Magyar Nemzeti Bank.

Gabriella Grosz is an Economic Analyst at the Magyar Nemzeti Bank. Email: groszg@mnb.hu Evelyn Herbert is an Analyst at the Magyar Nemzeti Bank. Email: herberte@mnb.hu Gábor Izsák is a Lawyer at the Magyar Nemzeti Bank. Email: izsakg@mnb.hu Katinka Szász is a Legal Referent at the Magyar Nemzeti Bank.Email: szaszk@mnb.hu

The authors would like to thank Alexandra Béres and Zsófia Tringer for their contribution to preparing the study.

The Hungarian manuscript was received on 15 June 2021.

DOI: http://doi.org/10.33893/FER.20.4.86117
} 


\section{Introduction}

In Hungary, the role of real estate is vitally important for both households and financial institutions, as the majority of the population live in their own property, which is financed by loans in many cases. Housing stock accounts for around 70 per cent of Hungarian households' real wealth, and around 80 per cent of them own their own property (MNB 2017). Real estate plays a major role in the operation of the financial sector, with a significant proportion of bank exposures secured by mortgages on real estate. At the end of 2020, mortgage loans backed by residential property amounted to more than HUF 4,500 billion, while commercial real estate mortgage loans amounted to more than HUF 3,000 billion. Together, this accounted for around 16 per cent of banks' operations in proportion to the balance sheet total. ${ }^{1}$

One essential requirement for efficient mortgage lending processes is that participants have up-to-date, accurate information on the parameters of the properties offered as collateral. Property valuation can also be relevant in other banking processes, for example when developing a preliminary loan appraisal or monitoring the value of the underlying property over the term of the loan. The property valuation commonly used in Hungary is essentially based on an inspection carried out on-site by an independent professional, the credibility and accuracy of which is in the best interests of both the lender and the prospective debtor, but is very costly and time-consuming.

In our study, within the context of mortgage lending, we focus on residential mortgage lending, as serving this segment accounts for a significant number of banks' lending processes including valuations, and the processes can be well standardised and play a key role in the functioning of the economy as a whole. One solution to overcome the above-mentioned obstacles to residential mortgage lending could be - in part - provided by the opportunity for the valuation of collateralised real estate without an on-site inspection, based on statistical data and models, which is also allowed by the legal framework for new lending from February 2021, under certain conditions. However, this method can often be limited by the fact that many credit institutions do not have available data based on which they could carry out valuations with sufficient accuracy. On the other hand, there are practical issues and regulatory gaps that support this type of valuation to a lesser degree. Providing access to real estate data for statistical valuation methods through a central database would, in our view, support financial institutions in developing digitised solutions making risk management more efficient and in terms of lending processes, it would allow for simpler and faster administration.

\footnotetext{
${ }^{1}$ Based on the data reporting of the Magyar Nemzeti Bank (the Central Bank of Hungary, MNB)
} 
In this paper, we provide a summary of the current situation of valuations relevant to the lending process in Hungary and internationally, and present the benefits and potential challenges of a central database for valuations. Section 2 describes the role and function of valuation processes in bank lending, as well as the methodology, advantages and disadvantages of on-site and statistical valuation methods. Section 3 reviews the legal environment and practical application of the statistical valuation method, and briefly describes some relevant features of the domestic housing loan market. Section 4 describes the requirements for the databases needed for the application and provides a brief outline of the data on real estate that are available in Hungary. Finally, Section 5 presents the theoretical operating model for a central database, outlining the opportunities and challenges for actors in the sector.

\section{The role of valuations in lending}

\subsection{Terminology related to property valuations and the on-site valuation process}

In the case of mortgage lending using real estate as collateral, the purpose of the loan is usually the purchase or construction of the property itself, which also serves as collateral for the loan. Real estate collateral provides the debtor with more favourable credit terms compared to an unsecured loan (Aczél et al. 2016), as it reduces the lender's risks by allowing the value of the collateral to be used to satisfy the debt in case of default, and therefore plays a significant role in lending; accordingly, knowing value of the collateral is of paramount importance. For decades, financial regulation has been challenged by the issue of accurately determining (estimating) the value of the property that is the collateral behind a mortgage loan, which is constantly changing depending on a number of macroeconomic and financial indicators. Housing market developments and in particular the volatility of housing prices influence the sector's savings and consumption decisions through the financial position of households, while these factors influence the portfolio, profitability and lending activity of financial institutions via the mortgage loan collateral (MNB 2021a).

When applying for a mortgage loan and determining the value of the property, a distinction must be made between the market value of the property and the value of the property taken into account in the lending process, the so-called mortgage lending value. The market value of the real estate is the market price of the debtor's property when selling it, normally estimated at arm's length under normal market conditions; $;^{2,3}$ determining the market value requires the services of an expert using

\footnotetext{
${ }^{2}$ See Article 1 of Government Decree 231/2015 (VIII. 12.) on the determination of the market value of the debtor's assets in the debt settlement proceedings of natural persons https://net.jogtar.hu/ jogszabaly?docid=a1500231.kor)

${ }^{3}$ Article 4(1)(76) of Regulation (EU) No 575/2013 of the European Parliament and of the Council on prudential requirements for credit institutions and investment firms and amending Regulation (EU) No 648/2012 (CRR) (26 June 2013) (https://eur-lex.europa.eu/legal-content/EN/TXT/?uri=celex\%3A32013R0575)
} 
various calculation methods. This is different from the mortgage lending value, which cannot be higher than the market value, as it is designed to ensure that the collateral guarantees the return on the loan granted by the credit institution over the long term ${ }^{4}$ and minimises the bank's losses in the event of default by the debtor. The mortgage lending value is usually the basis for the extent of lending or commitment, often capped by regulatory tools, ${ }^{5}$ and provides collateral for a claim and its charges. ${ }^{6}$

Banks expect the value of the property to be used as collateral for a loan to be determined by a valuation expert for the practical reason that the purchase price or market value negotiated by the parties at a given moment in time ("Market value") is not an accurate indication of the long-term (20-30 years) value of a property. In addition to the assessment of the consumer's ability to pay, the assessment of the long-term value of the property ("Mortgage lending value") is of particular importance, which is why the maximum amount of the loan that can be taken out is also capped - in a conservative approach, taking into account systemic effects at a stricter level than the previous one - in relation to the value of the property, as set out in the MNB's borrower-based measures ("Maximum LTV"). Compared to this, banks can be more restrictive according to their risk sensitivity ("Bank's internal limit") as seen in Figure 1.

\footnotetext{
${ }^{4}$ Decree 25/1997 (VIII. 1.) of the Minister of Finance on the methodological principles for defining the mortgage lending value of properties not qualifying as arable land (https://net.jogtar.hu/jogszabaly?docid=99700025. PM), Section 2 (1) "The mortgage lending value is the value of a property determined on the basis of a conservative estimate. In determining the mortgage lending value, account is taken of the specific risks arising from the long maturity of the loans disbursed by the lender and only those features of and returns on the property which are likely to accrue to any owner in the future."

${ }^{5}$ In Hungary, according to MNB Decree No. 32/2014. (IX. 10.) on the Regulation of the Debt service-to-Income Ratio and the Loan-to-Value Ratio (https://net.jogtar.hu/jogszabaly?docid=a1400032.mnb), Section 3 (1) "For forint loans secured by a mortgage on real estate as collateral, the value of the exposure at the time of the assessment of the loan application shall not exceed 80 per cent of the real estate's market value, and shall not exceed 85 per cent in case of financial leases. The market value of loans granted for facilities under construction refers to the expected market value at the time of full completion of the property".

${ }^{6}$ In the context of the valuation of real estate, additional supervisory requirements are set out in MNB Recommendation 11/2018 (II. 27.) on the management of real estate-related risks of financial institutions. ${ }^{7}$ MNB Decree No 32/2014. (IX. 10.) on regulation of the Debt service-to-Income Ratio and the Loan-to-Value Ratio
} 


\section{Figure 1 \\ Relationship between the market value and the mortgage lending value during the term of the loan}

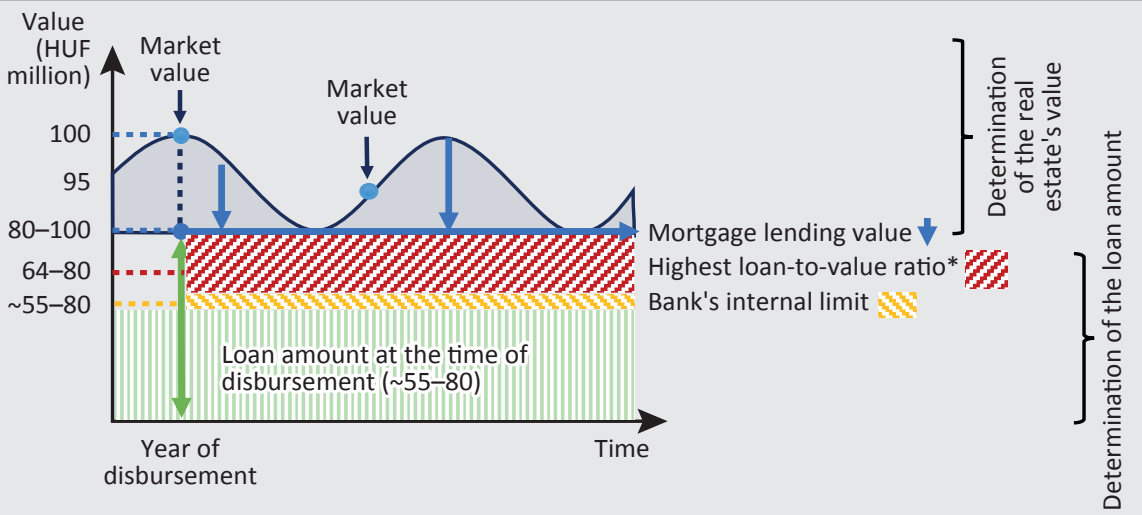

Note: * The maximum loan-to-value (LTV) is 80 per cent of the mortgage value of a household, HUFdenominated loan calculated with market data comparison or statistical methods. LTV is different for mortgage loans denominated in other currencies than forint and for leasing covered by real estate.

Source: Compilation based on Béres - Tringer (2020)

The cost and time required for loan disbursements secured by residential property is increased by the on-site inspection by an independent valuer, which costs around HUF $35,000-40,000^{8}$ and takes several days. The valuation process during lending, including also the on-site inspection, is summarised in Figure 2.

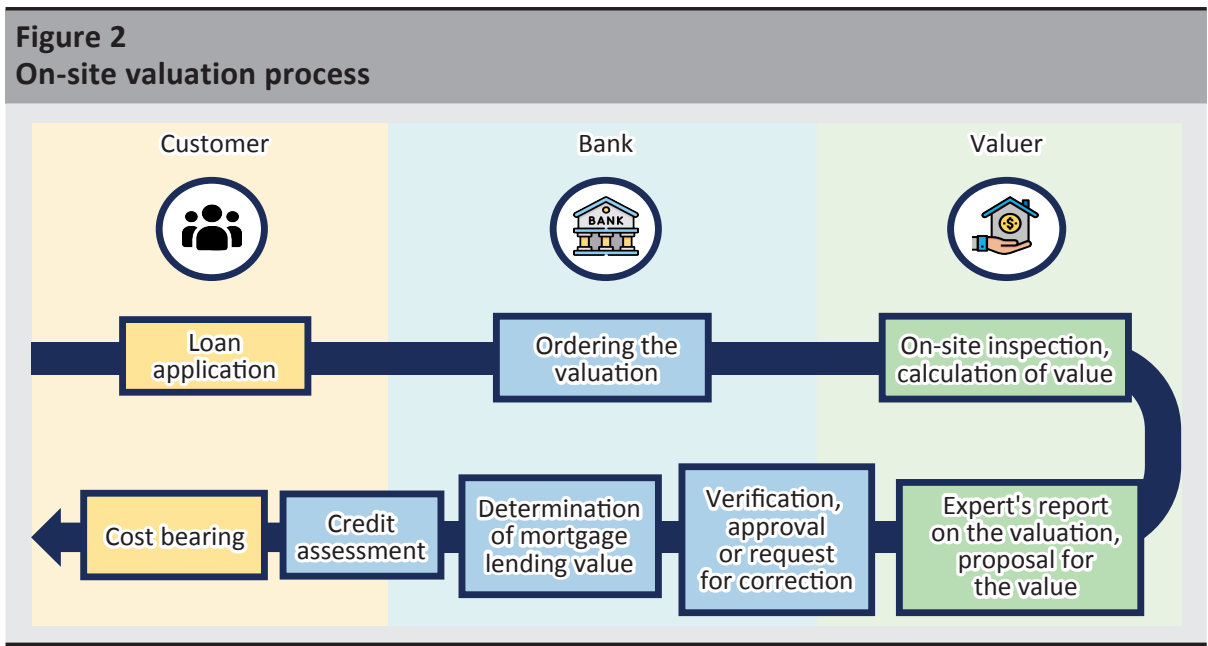

\footnotetext{
${ }^{8}$ https://www.erstebank.hu/hu/tudastar/maganszemelyek/hitelek/lakasepitesi-tamogatas/milyen koltsegekkel_kell_szamolni. Downloaded: 8 October 2021. https://granitbank.hu/upload/lakossag\%20egyeb/ T\%C3\%A1j\%C3\%A9koztat\%C3\%B3\%20a\%20GR\%C3\%81NIT\%20jelz\%C3\%A1loghitelekr\%C5\%91I_140710. pdf. Downloaded: 8 October 2021. https://lakashitel.raiffeisen.hu/?o=csok\&utm_source=raiffeisen\&utm medium=text\&utm_content=termekoldal\&utm_campaign=lakashitel_2021. Downloaded: 8 October 2021.
} 
The valuation is carried out by a valuer appointed by the bank and independent of the lending decisions. Based on Decree 25/1997 (VIII. 1.) of the Minister of Finance on the methodological principles for defining the collateral value of properties not qualifying as arable land (hereinafter referred to as the MoF Decree), market and legal aspects must be assessed when preparing the valuer's final report. In addition, during the inspection, the valuer will, inter alia, examine the immediate surroundings of the property, its accessibility, infrastructure, the use of the property, the size and conditions of the plot, the utilities, the description of the buildings and their structure and condition.

Following the on-site inspection, the valuer determines the market value of the property and proposes a mortgage lending value. Different valuation methods can be used to determine the value, such as valuation based on the analysis of comparative market data, valuation based on the calculation of yields and costbased valuation, and - as a general rule - at least two of these methods (but preferably all three) should be used. The MoF Decree allows the use of a single valuation method (valuation method based on the analysis of comparative market data on the basis of the MNB requirement ${ }^{9}$ ) under certain conditions, and this option is also regularly used by institutions.

After the valuation, including an on-site inspection by the valuer, the proposed value and the valuer's final report must be verified and approved by the lender, the procedure and rules for which must be laid down in the internal rules of procedure. If errors of substance or form found during the verification justify it, the bank may initiate a correction of the valuation. The amount of the mortgage lending value will ultimately be decided by the lender in accordance with its rules, but the value accepted cannot be higher than the value proposed by the valuer.

Although a valuation based on an on-site inspection may reveal risks that cannot be identified without other facts that affect the value of the property, the chances of these occurring are assumed to be lower in markets where properties are readily comparable on the basis of certain standard parameters, e.g. condominiums in a specific neighbourhood (Dippong - Harnos 2008, Chapter 3). At the same time, the cost and time required for an in-person valuation is significant and is a barrier to digitalising the lending process. The development of digitalisation in banking is a key objective internationally and in Hungary as well, as it can increase banking efficiency and thus reduce interest rates on loans paid by clients (MNB 2019). Moreover, the loan application process would be more convenient and faster if it were fully digitalised.

\footnotetext{
${ }^{9}$ Recommendation No 11/2018 (II. 27.) of the Magyar Nemzeti Bank on the management of real estate-related risks of financial institutions; (https://www.mnb.hu/letoltes/11-2018-ingatlan-ajanlas.pdf).
} 
Although on-site valuations are based on a detailed examination of the property's individual characteristics, incorporating the experience of the valuer, it is important to bear in mind that they are an estimate of the property's value and therefore do not result in a perfect 'market' price. This uncertainty is something that banks need to take into account in their risk management, as supported by the fact that examining the data of the past nearly 20 years in a sample of mainly developed countries, in the case of residential property the average difference between the average sales price and the valuer's estimate ranged widely (between 0 and 10 per cent) (MSCl 2019, Figure 7).

\subsection{General requirements for statistical valuation methods}

In recent years, technological advances and changing client needs have led to the spread and development of statistical valuation methods that do not require onsite inspections. These are methods based on mathematical, statistical models that perform valuations based on large amounts of extensive, detailed data on properties, without the need for an on-site inspection (RICS 2017). For some banking processes, such as refinancing or monitoring and reviewing property values, it was possible to use them in the past as well. In addition to the recent need for digitalisation and cost reduction, the coronavirus pandemic has highlighted the need to reconsider the rules related to on-site inspections. The domestic regulation has also reacted to the problem, as a result of which the MoF Decree, amended with effect from 5 February 2021, and the borrower-based measures of the MNB allow for the use of a statistical valuation method without an on-site inspection when granting loans (see Section 3.1. for details). Although in some cases onsite inspections will remain an unavoidable part of valuations, the widespread use of statistical valuation methods under the proper conditions is an important prerequisite for digitalisation, efficiency improvement and cost reductions in banking.

The European AVM Alliance $\left(E A A^{10}\right)$ has developed a detailed set of general requirements for statistical valuation models (EAA 2019), emphasising that detailed, accurate data, as well as extensive, objective backtesting, are necessary for the accuracy of results. The expectations are divided into two main groups: on the one hand, expectations related to operational aspects and, on the other hand, technical expectations related to the testing of models (Figure 3).

\footnotetext{
${ }^{10}$ The EAA is a European non-profit organisation that brings together valuers using automated valuation models (AVMs) for residential property. Their aim is to raise awareness of the benefits of AVMs, to represent the interests of AVM valuers and to create uniform standards for the use of AVMs.
} 


\section{Figure 3}

Operating mechanism of statistical valuation models

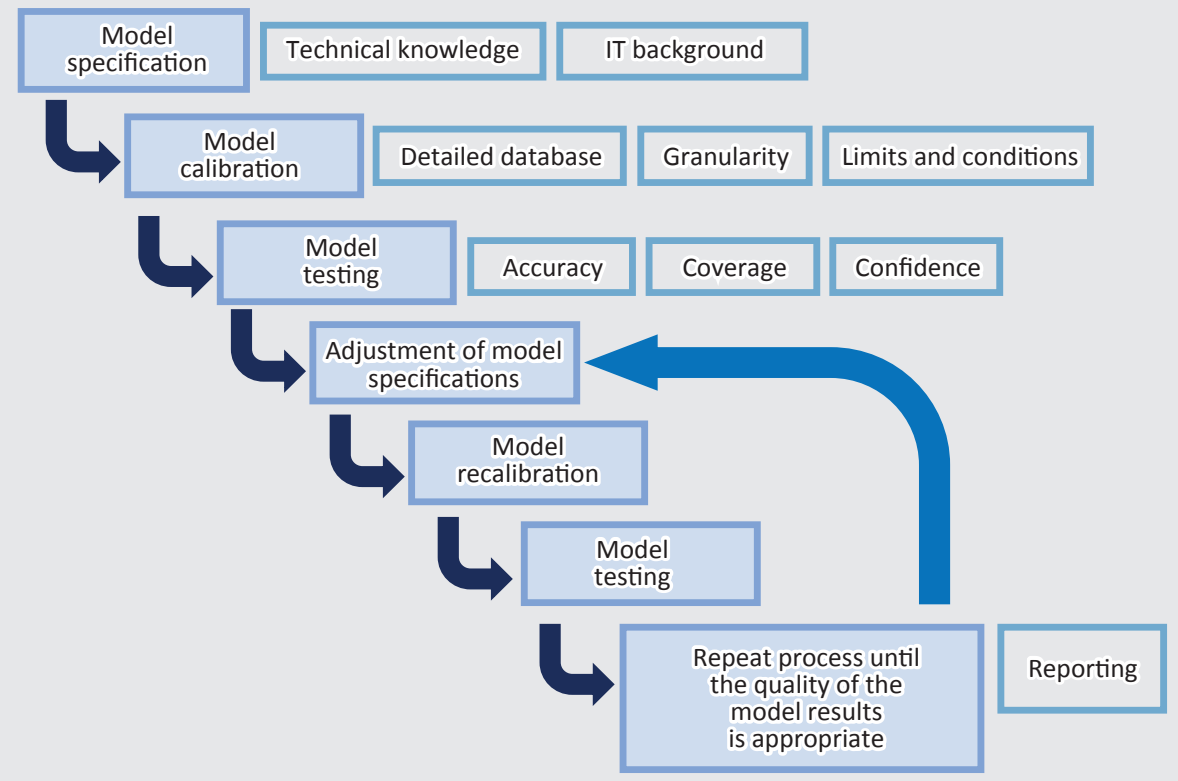

Source: Edited based on IAAO (2018) and EAA (2019)

\subsection{Statistical valuation methods and fundamental principles}

In fact, the term "statistical valuation method" covers a wide range of valuation models with varying complexity and data requirements, and therefore different purposes. These methods are presented according to the categorisation and description provided by the EAA (2019) (Table 1). ${ }^{11}$

\footnotetext{
${ }^{11}$ For a further categorisation of methods used for statistical valuation, see for example Horváth et al. (2016).
} 


\begin{tabular}{|c|c|c|c|c|}
\hline \multicolumn{5}{|c|}{$\begin{array}{l}\text { Table } 1 \\
\text { Characteristics of some statistical valuation methods }\end{array}$} \\
\hline & House price index & $\begin{array}{l}\text { Single parameter } \\
\text { valuation }\end{array}$ & Hedonic models & $\begin{array}{l}\text { Comparables } \\
\text { based automated } \\
\text { valuation models }\end{array}$ \\
\hline $\begin{array}{l}\text { Considers individual } \\
\text { property features }\end{array}$ & \multicolumn{2}{|c|}{ No } & Partially yes & Yes \\
\hline $\begin{array}{l}\text { Considers individual } \\
\text { location }\end{array}$ & \multicolumn{2}{|c|}{$\begin{array}{l}\text { Only predefined geographical } \\
\text { categories }\end{array}$} & $\begin{array}{l}\text { Geographical } \\
\text { categories and } \\
\text { individual } \\
\text { distances }\end{array}$ & Yes \\
\hline $\begin{array}{l}\text { Confidence indicator } \\
\text { for each individual } \\
\text { valuation }\end{array}$ & \multicolumn{2}{|c|}{ No } & \multicolumn{2}{|c|}{ Yes } \\
\hline $\begin{array}{l}\text { Previous value must } \\
\text { be available }\end{array}$ & Yes & \multicolumn{3}{|c|}{ No } \\
\hline $\begin{array}{l}\text { Property valuation } \\
\text { on an individual } \\
\text { basis }\end{array}$ & \multicolumn{2}{|c|}{ No } & Partially & Yes \\
\hline $\begin{array}{l}\text { Used to monitor } \\
\text { portfolio/market } \\
\text { trends }\end{array}$ & Yes & \multicolumn{3}{|c|}{ After conversion into a price index, yes } \\
\hline Source: Edited based & EAA (2019) & & & \\
\hline
\end{tabular}

\subsubsection{House price index}

The house price index is a time series of prices (usually grouped by area) for certain segments of real estate, which can be grouped using other dimensions, in addition to division by area. In Hungary, several published house price indices are available, the best known of which are the house price indices published by the MNB, Hungarian Central Statistical Office (HCSO) and Takarék. There are several methods for calculating the house price index, based on expert opinions, simple aggregation, the basket of goods method and the repeat purchases index, or hedonic regression in the case of domestic price indices. While this method does not require a strong technical IT background, the availability of an appropriate data set and the development of a methodology are also essential for this method. Eurostat (2013) provides detailed guidelines for the production of house price indices, as well as methodologies and best practices. 


\subsubsection{Single parameter valuation}

A single-parameter valuation estimates the value of a property based on a selected property characteristic (mostly based on the type of property, e.g. detached house, semi-detached house, condominium). The method is based on an average or median price for a given geographical area and period. It is generally used to determine an approximate initial property value subject to further in-depth analysis or to describe and monitor the evolution of the price level of a particular market.

\subsubsection{Hedonic models}

Hedonic models are multivariable methods that calculate the value of a property based on predetermined parameters, taking into account several property characteristics (e.g. property type, floor area, year of construction, number of rooms). Such models also assume that properties can be grouped according to their location, and that within the same group the same relationship between property characteristics and value can be observed for all properties. The parameters used are derived from a calibration dataset that includes property characteristics, data on values and additional socio-economic data for the geographical area (e.g. unemployment, average age of population, median income).

\subsubsection{Comparables based automated valuation models}

This method uses algorithms to select similar properties from a detailed, extensive property database, based on which the estimated property value is calculated automatically using complex mathematical models. These models assume that the value can be best estimated based on the value of the most similar properties, with similar properties being selected on the basis of property characteristics and location. 


\subsection{Use of statistical valuation methods from the perspective of the different participants involved in lending}

The emergence of statistical valuations affects different participants in the lending process in various ways, as illustrated in Table 2.

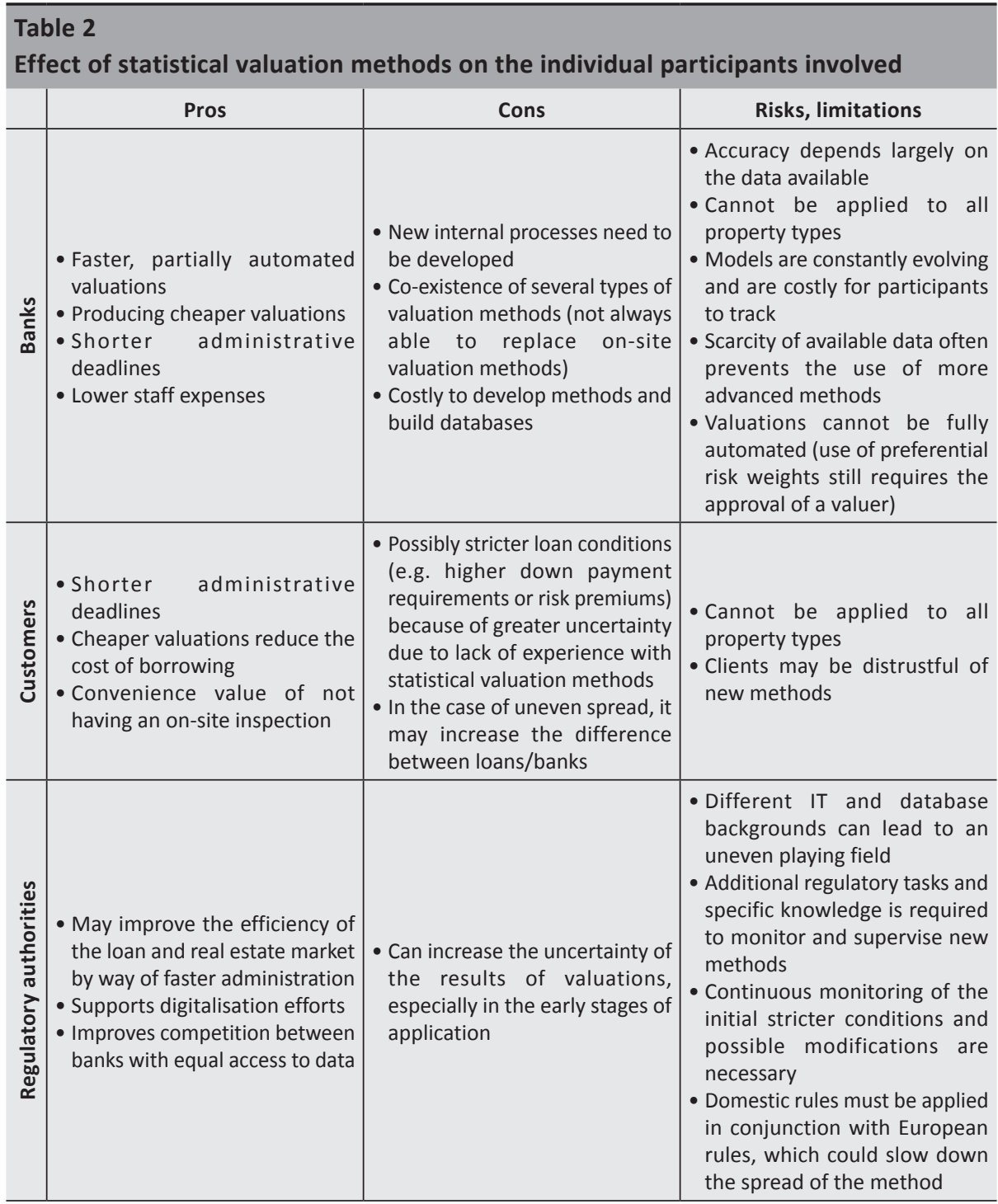


One of the most common risks associated with statistical valuation methods is the inability to take into account information based on an on-site inspection that may have a material impact on the value of an individual property. While this may indeed increase the uncertainty of valuations, statistical valuations based on a large data set can reveal correlations between house prices and environmental/ property characteristics that are not available in the case of traditional, onsite valuations involving also an on-site inspection due to the valuer's limited information base not including statistical data. Békés et al. (2016) also showed that, in addition to the individual characteristics of properties, the geographic characteristics, agglomeration and income position of municipalities also contain important information for the determination of property prices. Furthermore, the accuracy of valuations can be significantly improved without an on-site inspection if the available data is extended. The accuracy of a statistical valuation based on a sufficient quantity and quality of data may therefore not be inferior to a traditional on-site valuation based on on-site inspection.

One of the key advantages of statistical valuation methods is that they provide results faster than on-site valuations. This has tangible benefits for both clients and banks. However, faster administration can make not only lending processes but also housing market processes more efficient. Indeed, the use of statistical valuations is expected in the first instance for dwellings, including prefab concrete block flats (Table 4), as these types of property are well categorised and have fewer individual characteristics. The time to sell for such block flats is the shortest of all property types - only 2 months (MNB 2021a) - so accelerating the lending process could be of particular importance.

\section{Current state of on-site and statistical valuations in the EU and Hungary}

\subsection{Legal environment}

The EU regulatory framework clearly creates the possibility for credit institutions to use statistical valuation methods to assess the value of property that serve as collateral in mortgage lending when monitoring and revaluing the value of property. However, the CRR contains neither specific rules for new lending, nor explicit exclusionary provisions. However, it stipulates that the valuation of collateral must always be carried out by an independent valuer. According to the European Banking Authority (EBA) guidelines, ${ }^{12}$ the value is not automatically assessed by accepting

\footnotetext{
${ }^{12}$ Guidelines on loan origination and monitoring, published on 29 May 2020 https://www.eba.europa.eu/ sites/default/documents/files/document_library/Publications/Guidelines/2020/Guidelines\%20on\%20 loan\%20origination\%20and\%20monitoring/884283/EBA\%20GL\%202020\%2006\%20Final\%20Report\%20 on\%20GL\%20on\%20loan\%20origination\%20and\%20monitoring.pdf
} 
the value given by the model, but statistical methods serve as a tool, based on which the independent valuer who remains involved in the process determines the value.

The use of statistical valuation methods is also regulated by the capital requirement rules set out in the CRR. For real estate, ${ }^{13}$ institutions can only consider an exposure or a part of an exposure to be completely secured if the taxative criteria set out in the regulation are met, e.g. the value of the real estate is regularly monitored and the collateral is insured. ${ }^{14}$ Based on the CRR and the EBA guidance referred to above, it can be concluded that real estate collateral valued using a statistical methodology can only be taken into account as a mitigating item in the determination of capital requirements for credit risk if the reliability of the estimated market value determined from the model output is individually reviewed (adjusted if necessary) by the independent valuer and is validated on a residential property-by-residential property basis. ${ }^{15}$ This does not imply the need to carry out an on-site inspection, but it does imply verification based on the valuer's expertise and other information available to them.

As mentioned above, Member States may make extensive use of statistical valuation where their national legislation so allows. In Hungary, in order to limit the risk exposure, before deciding to originate a mortgage loan, credit institutions must verify the existence and fair value of the required collateral, ${ }^{16}$ which must be determined in accordance with the rules set out in the MoF Decree. The MoF Decree allowed all credit institutions to apply statistical valuation methods for new loans from 5 February 2021, under the following conditions: ${ }^{17}$

a) the property underlying the valuation is classified as a residential property and has a maximum floor area of $150 \mathrm{sqm}$;

b) is located in Budapest, a county seat, a city with county rights or in the Budapest agglomeration;

c) in the calendar year preceding the valuation, there have been at least 10 property sales in the municipality/district in question, with a difference in specific price of up to 30 per cent;

d) the loan-to-value (LTV) ratio for a given transaction may be no higher than 60 per cent.

\footnotetext{
${ }^{13}$ See Articles 47c, 125(2)(d) and 126(2)(d)

${ }^{14}$ For more details, see: Articles 208 and 229 of the CRR

${ }^{15}$ EBA Guidelines Section 210

${ }^{16}$ Based on Section 99 of Act CCXXXVII of 2013 on Credit Institutions and Financial Enterprises (https://net. jogtar.hu/jogszabaly?docid=a1300237.tv)

17 See Annex 5 to the MoF Decree
} 


\subsection{Features of the Hungarian housing market}

Domestic lending for housing is growing dynamically, with new mortgage origination averaging over HUF 900 billion annually over the past 2 years (MNB 2021b). However, the geographical distribution of lending is not even, with the most housing loans originated in Budapest and Pest county, while the smallest number of housing loans have been granted in Nógrád and Tolna counties since 2019, which correlates with county population data (Figure 4).

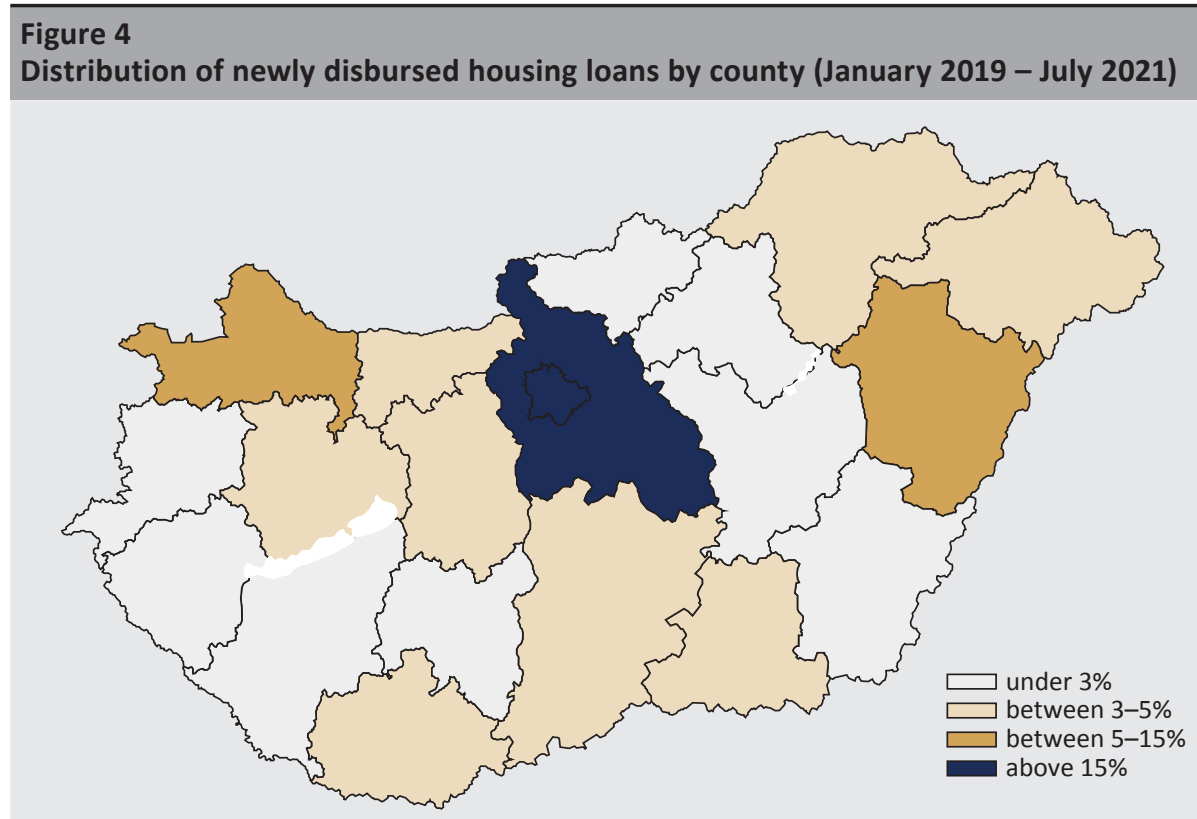

Note: Distribution of new housing loans disbursed by county during the period as a share of total new housing loans over the period.

Source: MNB

However, housing lending varies significantly not only by region but also by type of municipality, especially when looking at the portfolio of individual banks. In this regard, we can see that some financial institutions are more active in lending in the capital/metropolitan areas, while others are strong in housing loans in smaller municipalities (Figure 5). 


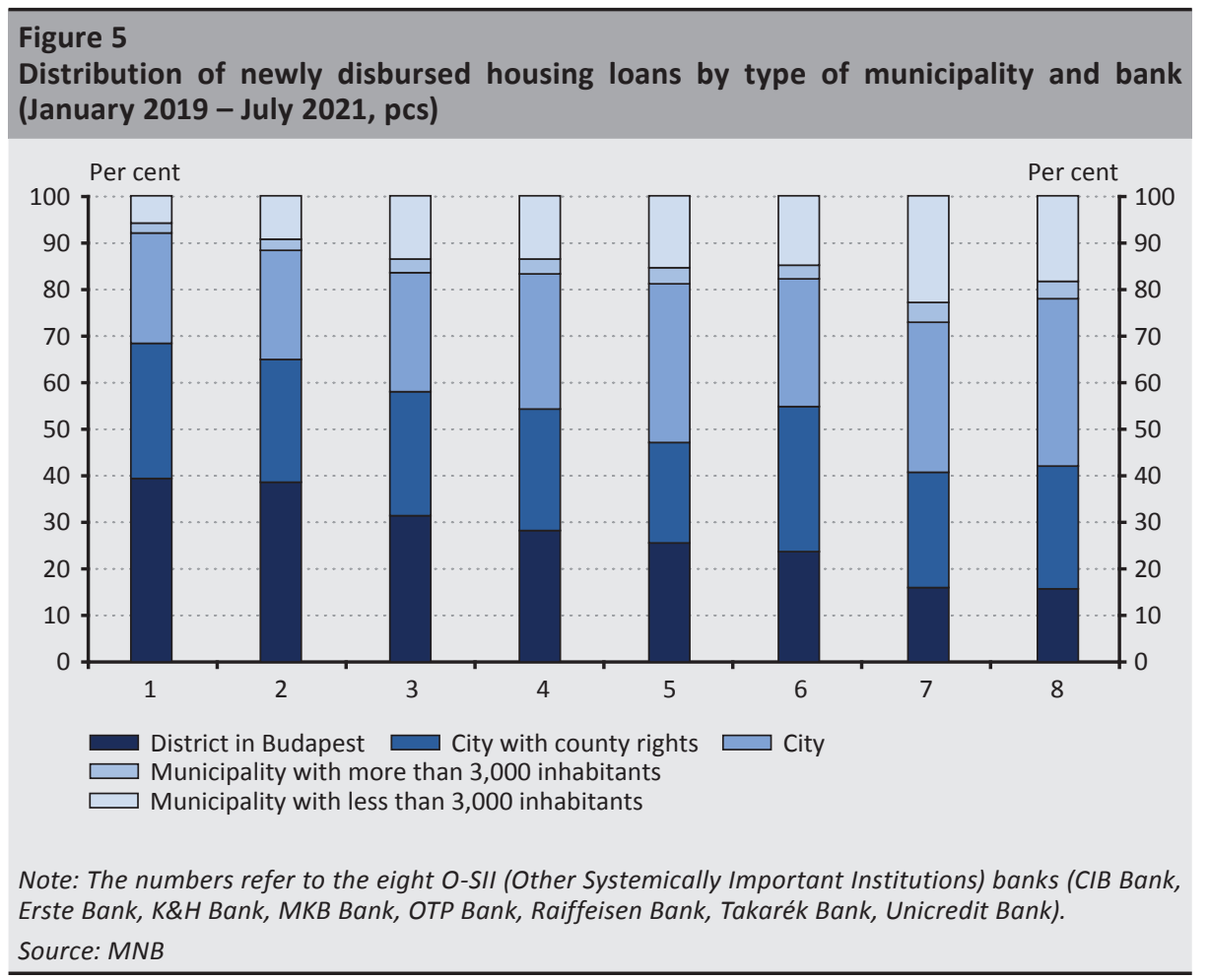

Newly disbursed housing loans can also be further analysed by the type of property financed. This is also important in the context of statistical valuation, because not all types of property can be valued using this method, and a certain number of contracts are needed for banks to have adequate amount of data on each type of property. The available data show that banks finance primarily single-family houses and apartments; therefore, statistical valuation may start with these property types - or a subset of them - first in the apartment market, due to the smaller importance of individual characteristics in this property segment (Figure 6). 


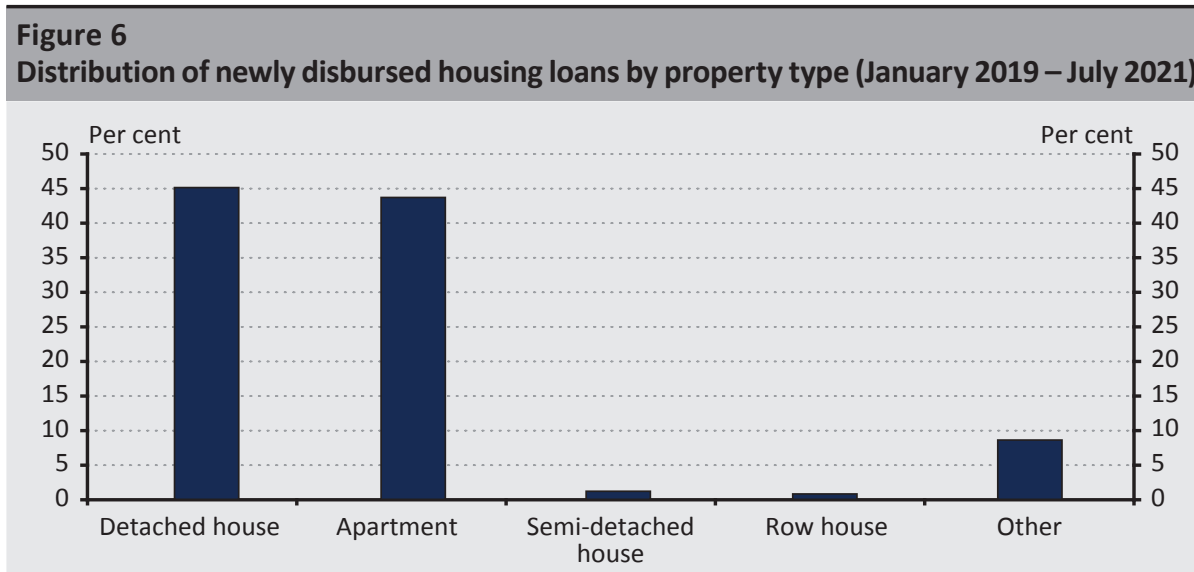

Note: The other category covers holiday homes, garages, offices, shops, unbuilt and other residential property collateral. Estimate based on the collateral with the highest value.

Source: $M N B$

The MoF Decree sets several conditions for the use of statistical valuation, and thus it is worth examining the potential scope affected by the possibility of valuation without on-site inspection, based on the lending in recent years. In addition to the conditions in the MoF Decree, we also examined the state-subsidised character of the loans, as these loans are subject to a statutory requirement for an on-site inspection. The strongest criterion was the LTV criterion (Annex 5, Section 2.d of the MoF Decree), while the weakest criterion was the square metre-based criterion (Figure 7).

\section{Figure 7}

Estimate of the proportion of properties eligible for statistical valuation methods (January 2019 - July 2021)

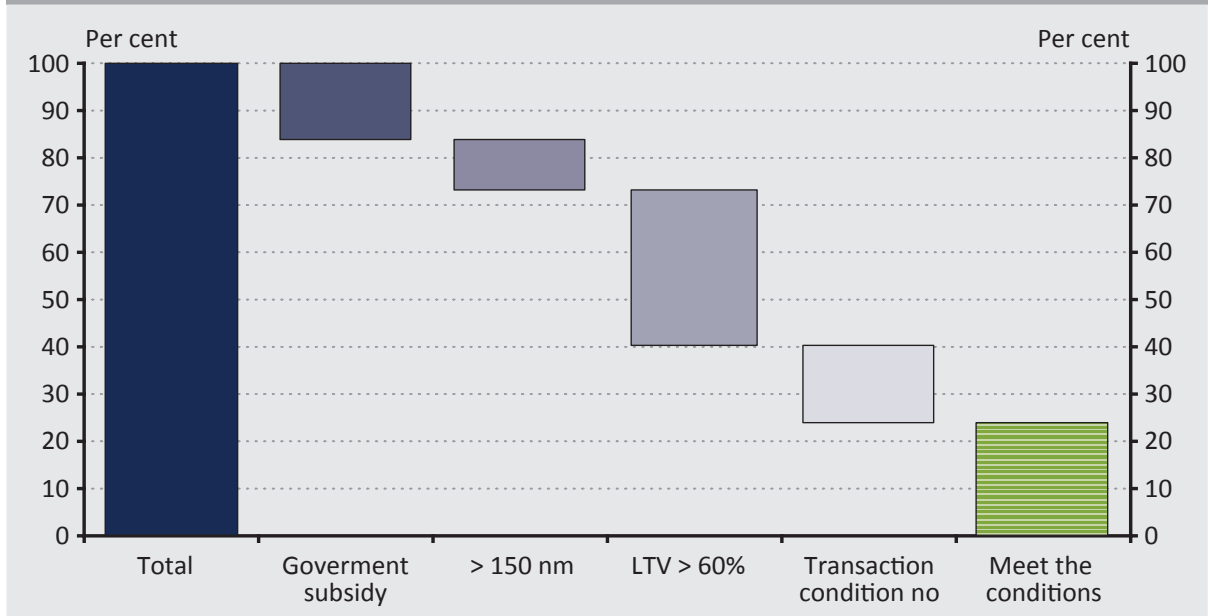

Note: The settlement transaction condition is a value calculated on the basis of the 2019 data from the NTCA property transaction database.

Source: National Tax and Customs Administration, MNB 
Overall, the number of properties that can be valued using statistical valuation methods may be significant: around 20-30 per cent of market mortgages secured by residential properties disbursed since 2019 may have met the requirements set by the MoF Decree, which is on the order of $50,000-70,000$ transactions in the last 2.5 years. ${ }^{18}$

\subsection{Use of valuations in practice}

In order to learn about the legal background and experience with the use of statistical valuation methods, the MNB conducted a survey of European practices in the summer of $2020 .{ }^{19}$ Based on the responses from the central banks (or supervisory authorities) of the 14 countries that responded to the survey, the national legal framework typically allows for the use of statistical valuation methods for different purposes, but most countries explicitly provide for this legal possibility only for monitoring (Table 3). Practical experience also follows the legislative environment, in some cases with certain restrictions (transaction number-based limits in the Czech Republic, existence of prior valuation and loan amount limits in Germany).

\section{Table 3}

Spread of statistical valuation methods internationally in practice

\begin{tabular}{l|c|c|c|c|c|c|c|c|c|c|c|c|c} 
& DK & ES & HR & MT & CZ & FI & DE & SI & RO & PL & LT & LV & NO \\
\hline Loan origination & $x$ & $x$ & $x$ & $x$ & $\checkmark$ & $\checkmark$ & $\checkmark$ & $x$ & $x$ & $x$ & $x$ & $\checkmark$ & - \\
\hline Refinancing & $\checkmark$ & $x$ & $x$ & $x$ & $\checkmark$ & $\checkmark$ & $\checkmark$ & $x$ & $x$ & $x$ & $x$ & $\checkmark$ & - \\
\hline Monitoring & $\checkmark$ & $\checkmark$ & $\checkmark$ & $\checkmark$ & $\checkmark$ & $\checkmark$ & $\checkmark$ & - & $\checkmark$ & $\checkmark$ & $\checkmark$ & $\checkmark$ & $\checkmark$ \\
\hline
\end{tabular}

Note: In the case of a red box, no institution uses it, light green ticks indicate that some institutions use it, medium green ticks mean widespread use, dark green ticks mean that it is used by all institutions.

Source: MNB survey

At the beginning of 2021, the MNB also surveyed domestic banks on the needs formulated and risks identified related to statistical valuation methods. ${ }^{20}$ Based on the responses (10 banks, covering 95 per cent of the retail mortgage loan portfolio ${ }^{21}$ ), banks plan to use statistical valuation methods in a wide range of banking processes within the next year (Table 4). The majority of respondents would use statistical valuation methods for up to 30 per cent of their housing lending within three years, ${ }^{22}$ as the majority of respondents believe that this would reduce the cost of valuation by 50-80 per cent. At the same time, almost all banks indicated

\footnotetext{
${ }^{18}$ State-subsidised housing loan transactions were disregarded, as the law currently requires a mandatory on-site inspection for them.

${ }^{19}$ International questionnaire on the legal environment for the statistical valuation method (MNB 2020 survey)

${ }^{20}$ Survey on domestic financial institutions' plans for the statistical valuation method (MNB 2021 survey)

${ }^{21}$ Based on the stock of mortgages secured by residential mortgages in December 2020

${ }^{22}$ OTP already provides its potential clients with an option to informative statistical valuation service https:// www.otpip.hu/online-ertekbecslo-kalkulator
} 
that they plan to impose stricter conditions on the use of statistical valuation methods than those set out in the MoF Decree (e.g. additional restrictions by area or property type, restrictions by loan type, stricter LTV requirements).

\begin{tabular}{|c|c|c|c|c|c|c|c|c|}
\hline \multicolumn{9}{|c|}{$\begin{array}{l}\text { Table } 4 \\
\text { Domestic banks' practices and future plans for statistical valuation methods used in } \\
\text { their lending processes }\end{array}$} \\
\hline & \multicolumn{2}{|c|}{$\begin{array}{c}\text { Preliminary credit } \\
\text { appraisal }\end{array}$} & \multicolumn{2}{|c|}{ Credit appraisal } & \multicolumn{2}{|c|}{ Value-review } & \multicolumn{2}{|c|}{ Revaluation } \\
\hline & Currently & Plans & Currently & Plans & Currently & Plans & Currently & Plans \\
\hline 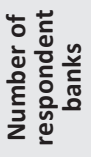 & 0 & 6 & 0 & 9 & 3 & 6 & 3 & 5 \\
\hline 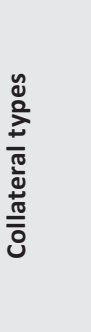 & & $\begin{array}{l}\text { Flat } \\
\text { Residential } \\
\text { property } \\
\text { broken } \\
\text { down into } \\
\text { units }\end{array}$ & & $\begin{array}{l}\text { Flat } \\
\text { Residential } \\
\text { property } \\
\text { broken } \\
\text { down into } \\
\text { units } \\
\text { Properties } \\
\text { under the } \\
\text { MoF } \\
\text { Decree }\end{array}$ & $\begin{array}{l}\text { Flat } \\
\text { Detached } \\
\text { house } \\
\text { All } \\
\text { residential } \\
\text { properties }\end{array}$ & $\begin{array}{l}\text { Flat } \\
\text { Residential } \\
\text { property } \\
\text { broken } \\
\text { down into } \\
\text { units }\end{array}$ & $\begin{array}{l}\text { Flat } \\
\text { Detached } \\
\text { house } \\
\text { All } \\
\text { residential } \\
\text { properties } \\
\text { Agricultural } \\
\text { land }\end{array}$ & $\begin{array}{l}\text { Flat } \\
\text { All } \\
\text { residential } \\
\text { properties } \\
\text { Properties } \\
\text { under the } \\
\text { MoF } \\
\text { Decree }\end{array}$ \\
\hline
\end{tabular}

Note: The types of collateral shown are non-standardised responses provided by responding institutions on a descriptive basis.

Source: Compiled based on the MNB 2021 survey

\section{Availability and access challenges of data needed for statistical valuation internationally and in Hungary}

For the success of statistical valuation methodologies and the accuracy of valuations, the content and quality of the underlying data set and the structure of the database containing this data set are of key importance. In addition to the legal applicability discussed above, one major barrier to the adoption of statistical valuation methods by market participants is the lack of access to appropriate data, which is difficult to remedy without legislative support: larger, better-informed institutions may develop data monopolies, while smaller institutions may be at a significantly greater disadvantage and thus be able to lend at a higher cost, weakening competition in the credit market. The information monopoly of banks that build up large databases can amplify structural systemic risks if certain actors dispose over much more and better information than their competitors. Financial institutions with smaller databases can only carry out poorer quality, slower and more expensive 
collateral valuation, which can have a negative impact on their competitors using large databases, even at systemic level, through their potential losses. ${ }^{23}$

\subsection{International situation}

In its questionnaire survey carried out in summer 2020, the MNB paid particular attention to the availability of databases that could be used by the countries to carry out statistical valuations. The responses showed that, without exception, all countries use data from both public and non-public databases (Table 5).

\begin{tabular}{l|c|c|c|c|c}
\hline $\begin{array}{l}\text { Table 5 } \\
\text { Types of databases available in each country for statistical valuation }\end{array}$ \\
\begin{tabular}{l|c|c|c|c|} 
Government \\
database
\end{tabular} & $\begin{array}{c}\text { Buildings } \\
\text { registry }\end{array}$ & $\begin{array}{c}\text { Real estate } \\
\text { register }\end{array}$ & $\begin{array}{c}\text { Exchequer } \\
\text { database }\end{array}$ & $\begin{array}{c}\text { Real estate } \\
\text { transaction } \\
\text { database }\end{array}$ & $\begin{array}{c}\text { Statistical data, } \\
\text { house price } \\
\text { index }\end{array}$ \\
\cline { 2 - 6 } & $\mathrm{DK}$ & $\mathrm{PL}$ & $\mathrm{PL}$ & $\mathrm{CZ}, \mathrm{HR}, \mathrm{LT}, \mathrm{PL}$ & $\mathrm{DE}, \mathrm{FI}, \mathrm{MT}, \mathrm{RO}$ \\
\hline $\begin{array}{l}\text { Non- } \\
\text { governmental } \\
\text { information }\end{array}$ & $\begin{array}{c}\text { Valuation } \\
\text { databases }\end{array}$ & $\begin{array}{c}\text { Banking } \\
\text { Association } \\
\text { database }\end{array}$ & $\begin{array}{c}\text { Service } \\
\text { providers' } \\
\text { database }\end{array}$ & $\begin{array}{c}\text { Advertisement } \\
\text { data on real } \\
\text { estate portals }\end{array}$ & $\begin{array}{c}\text { Valuations of } \\
\text { external valuers }\end{array}$ \\
\cline { 2 - 6 } & $\mathrm{DK}, \mathrm{ES}, \mathrm{HR}$ & $\mathrm{PL}$ & $\mathrm{DE}, \mathrm{DK}, \mathrm{Fl}, \mathrm{LV}$, & $\mathrm{CZ}$ & $\mathrm{CZ}$ \\
\hline
\end{tabular}

Note: The table shows the responses to the following question: "From what kind of databases, data sources do the internal and external appraisers of credit institutions get data for the use of statistical valuation models, methods?"

Source: Edited based on the MNB 2020 survey

Several European examples show that unified efforts are beginning to unfold in the professional fields involved in property valuation with the goal of creating multifunctional databases that can provide more accurate, faster and more costeffective data to authorised parties. In 2015, the National Association of Romanian Valuers (ANEVAR) created the so-called BIG database, in which all valuers are obliged to enter the data of their valuation reports. The database contains anonymised data in addition to the mortgage lending value of the property and can also be accessed by financial institutions, in addition to valuers (Stan 2015). In Latvia, the most widely used database is the privately owned Cenu Banka, ${ }^{24}$ which provides real estate transaction data. The database connects several data sources (e.g. the property market database of the real estate register) and offers the possibility to filter the data according to different parameters or even to mark the search area on a map. In Denmark, the accuracy of the statistical valuation has become a matter of political debates in recent years, given that it has been used for decades to determine the annual property tax that owners have to pay. ${ }^{25}$ The valuation itself is carried out

\footnotetext{
${ }^{23}$ On market failures causing structural systemic risks, see Freixas et al. (2015) Chapter 5

${ }^{24}$ https://cenubanka.Iv/en. Downloaded: 8 October 2021.

${ }^{25} \mathrm{New}$ Danish Property Assessments. https://lead-roedl.dk/en/nye-ejendomsvurderinger/. Downloaded: 8 October 2021.
} 
by the local authority, with data available from the national land register (Wolters 2002). However, the data used from the land register were not sufficient to give an accurate picture of the true market price of a property. In response to these problems, the current government has extended the range of data that can be used, so that from 2021, the valuation can take into account photographs of the property, local features (e.g. forest, sea, access to transport) and, as a reference, transaction prices of properties sold in the area. ${ }^{26}$

\subsection{Situation in Hungary}

In Hungary, there are also a number of databases containing real estate data, both public and private (Figure 8), the availability of which would greatly assist lenders in providing accurate statistical valuations.

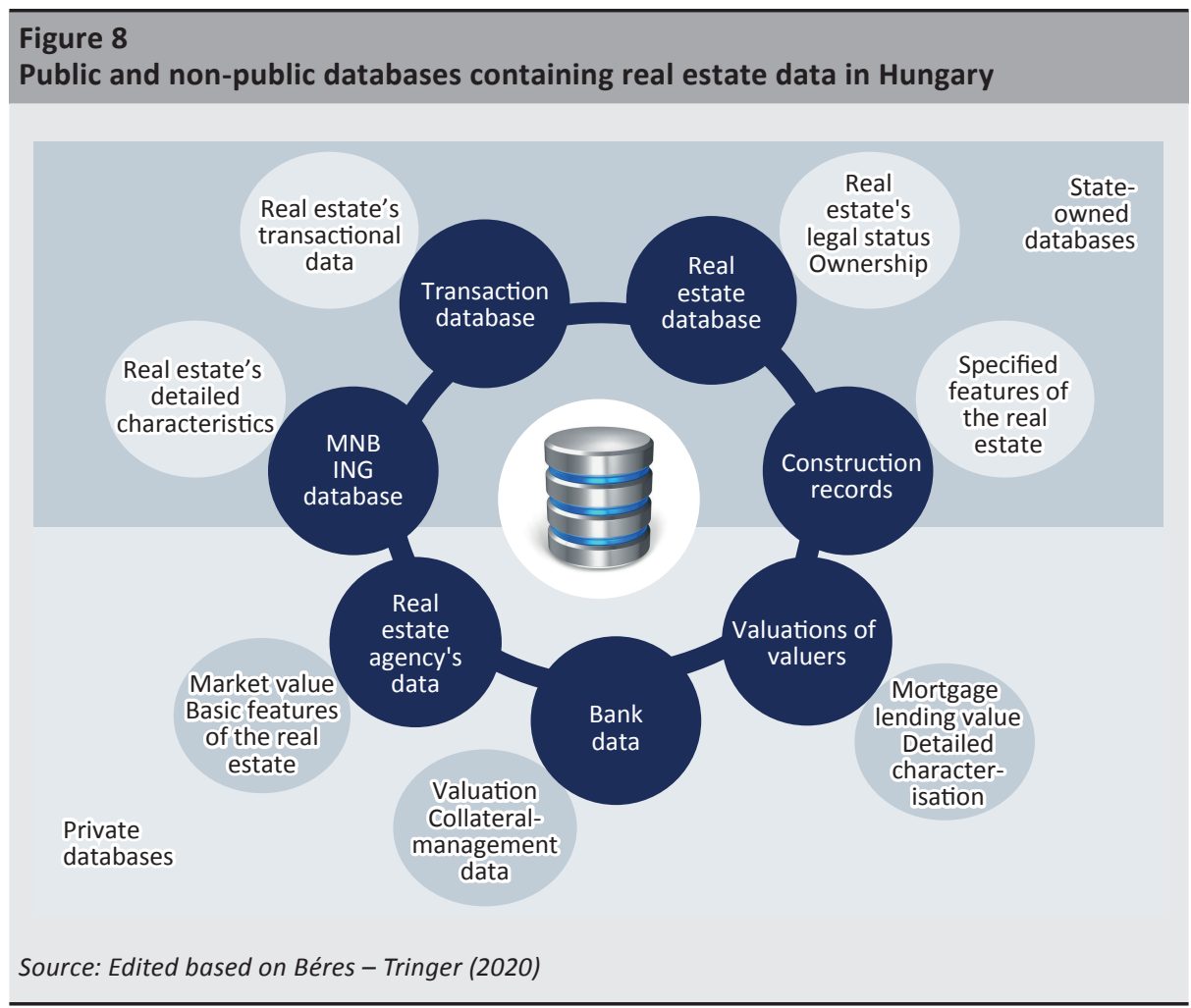

\footnotetext{
${ }^{26}$ https://lead-roedl.dk/en/nye-ejendomsvurderinger/. Downloaded: 8 October 2021.
} 
Levy database managed by the NTCA: the NTCA maintains a database based on the contract value of the property involved in the transaction in order to determine the appropriate level of levy for the transfer of real estate.

Land register kept by the Land Registry: the data in the title deeds on which the register is based, certify the rights, facts and changes in ownership of the property in question, in an up-to-date and complete manner, while ensuring public authenticity. ${ }^{27}$

Data managed by bank valuers, valuer's final report: valuer's final reports contain the broadest range of data that may be necessary to create a central database. The report includes a wide range of information affecting the pricing of the property concerned, as well as photographs that greatly support the possible replacement of a site inspection. ${ }^{28}$

Real estate sites: real estate sites generally populate their databases with the data content provided by the seller/landlord, but for larger real estate sites it is common practice for the data to be validated by the intermediary. The central element of the register is the offer price, but in addition to the size and layout of the property, it also includes other characteristics that affect the indicated sale price.

The National Construction Register (5 sub-registers) operated by the Lechner Knowledge Centre: a central system of web-based, database-driven IT applications serving the construction sector, operated by Lechner Non-profit Ltd. on its own IT infrastructure. The register consists of 5 database ${ }^{29}$ which contain data on properties that can be used for a wide range of purposes. ${ }^{30}$

MNB Real Estate Transaction Database (MNB ING): The MNB collects a wide range of information on financed residential real estate in Hungary as part of its supervisory activities, extending the institutional data reporting, which could also potentially serve as input for a central database in the future. ${ }^{31}$

Domestic banks are increasingly seeking to rely on databases from a variety of sources, not only for their statistical valuations, but also for their on-site valuations. From among the (10) banks surveyed by the MNB, 4 or 5 currently use one of the databases described above, but all respondents would use this information in the future (Table 6).

\footnotetext{
${ }^{27}$ Part Two of Act CXLI of 1997 on the Real Estate Registry https://net.jogtar.hu/jogszabaly?docid=99700141.tv

${ }^{28}$ See Annex 4 to the MoF Decree

${ }^{29}$ Electronic Documentation System Supporting Building Authority Licensing Procedures (ÉTDR), e-construction log, e-Utility, e-certification, Cultural Heritage Protection

30 https://lechnerkozpont.hu/oldal/e-epitesugy. Downloaded: 8 October 2021.

${ }^{31}$ The register contains, in addition to the data on real estate sales transactions that become known to financial institutions in the course of financing, detailed information on the real estate subject to the sale from the valuation related to the financing and, as regards the data used to identify the real estate, from the land registry.
} 


\begin{tabular}{|c|c|c|c|c|}
\hline \multicolumn{5}{|c|}{$\begin{array}{l}\text { Table } 6 \\
\text { Domestic banks' practices and future plans for the use of certain available } \\
\text { databases }\end{array}$} \\
\hline & \multicolumn{2}{|c|}{ For on-site valuations } & \multicolumn{2}{|c|}{ For statistical valuation methods } \\
\hline & Currently uses & Plans to use & Currently uses & Plans to use \\
\hline Valuations of valuers & 5 & 5 & 0 & 4 \\
\hline Real estate agency database & 4 & 5 & 1 & 7 \\
\hline Own banking database & 4 & 8 & 2 & 10 \\
\hline Transaction database & 4 & 7 & 4 & 10 \\
\hline
\end{tabular}

Note: The colour of the boxes indicates the number of respondents: red (0), orange (1-3), yellow (4-6), green (7-10). Respondents cover 95 per cent of household lending by credit institutions backed by residential property (December 2020).

Source: Plotted based on the MNB 2021 questionnaire survey

\subsection{Factors hindering domestic data availability}

At present, the databases available in Hungary typically operate separately, and the data are often inaccurate or incomplete: consequently, access and usability are far from optimal. In addition, another issue is posed by the fact that the content of certain databases may be further reduced by regulatory changes, rendering the already limited data access even more difficult.

Obtaining the data needed to carry out a statistical valuation from fragmented databases that are difficult to link together requires significant time and money. This creates a competitive disadvantage for smaller institutions that do not have sufficient data in their own portfolios and have to turn to external sources. Even for larger institutions, access to verified data from different sources on a single, central platform would bring significant improvements. Based on the MNB's 2021 questionnaire survey, a market need to develop adequate and widespread access to real estate data assets is also clearly identified.

\section{A proposal supporting the spread of statistical valuation methods in Hungary}

Based on our proposal, a central database would be established in Hungary, which would contain for each property the data necessary for the statistical real estate valuation. The database would primarily integrate the content of existing registers. The central availability of data under uniform conditions will ensure that all actors have access to uniform information of equivalent quality for valuations via the same channel, thus creating a level playing field and stimulating competition in the development of valuation models and competition in the credit market, pushing the market towards cost efficiency and lower lending rates. 
The creation of a separate database may be justified, as in that case it is not necessary to adapt to the data structure of any of the existing data providers, and as a separate system it is easier to make changes to it. In addition, due to the unique purpose of use, it requires a specific use and operational regime, the development of which may be more appropriate in a stand-alone system (e.g. information on a property can only be provided if the required amount of data on the property is already available). Particular attention must also be paid to adequate data quality: data from different databases must be matched, collated and cleaned to produce reliable value estimates based on these data.

\subsection{Basic requirements for the central database}

In designing the central database, it is important to ensure the availability a wide range of anonymised data to the sector, as this can best support the sophistication of risk management models and can also form the basis for conducting valuations at the time of loan origination without the need for on-site inspections (Figure 9).

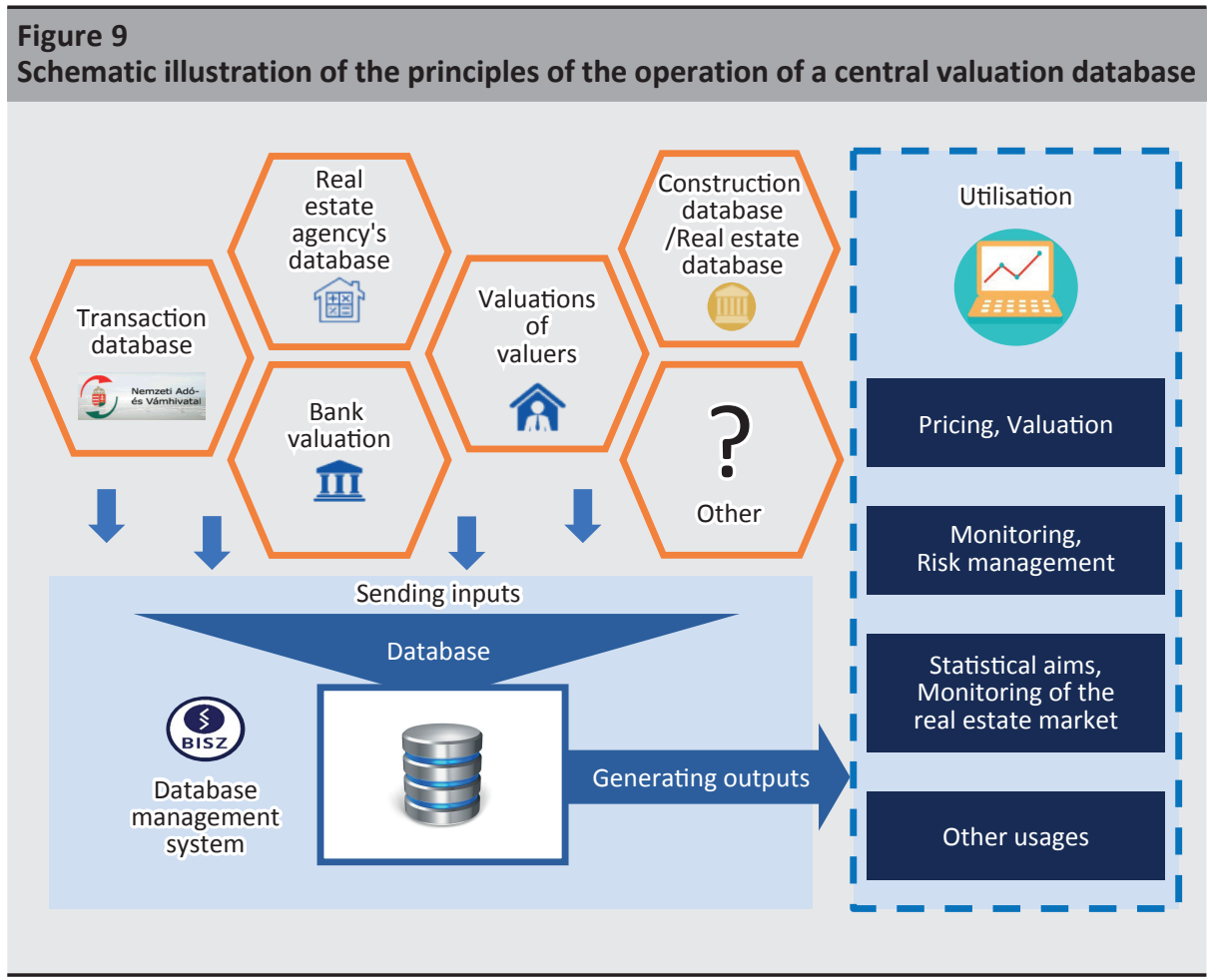


Different "databases" have different methodologies and data sets recorded at different times. In this context, it is necessary to ensure with respect to the data relating to the property

- connectivity: the most common identifiers for properties are a combination of the name of the municipality, the lot number and the exact address (municipality name, postcode, name of the public area, type of public domain, house number, floor, door);

- resolving inconsistencies between data: temporal and methodological differences between the data records of different "databases" and misrecordings sometimes result in contradictory information, and therefore it is necessary

- to ensure that the circumstances in which the data were generated (when the data were generated, what is the source of the information) are known;

- to develop an appropriate structure (definitional framework) to ensure the standardisation of data;

- to develop techniques to filter out and manage such contradictory information.

The design should take into account that the operating model should not create a competitive advantage/disadvantage for the actors in the sector, purely due to regulatory activity, by using IT solutions that are not available to all institutions or that would be disproportionately difficult and/or costly to implement. The institutions probably should be able to adapt quickly, with their own mechanisms and infrastructures, to the operational model developed for statistical valuation without on-site inspection, but it must be taken into account that not all actors will be able to prepare adequately for the launch of the system. To this end, the regulatory, oversight and (data) service provider side should strive for as much automation as possible from the start of the system, and for technological solutions that take into account the needs and tools of the user side.

Given that personal data will be processed when the data are entered into the database, appropriate data protection safeguards should be put in place for the information entered and processed centrally. The EU General Data Protection Regulation (GDPR) ${ }^{32}$ contains strict rules on the processing of data subjects' data. Article 5 of the GDPR gives a taxative list of principles that must be taken into account when processing personal data. In this context, it should be stressed that data must be processed for a specific purpose, only to the extent necessary and

\footnotetext{
${ }^{32}$ Regulation (EU) 2016/679 of the European Parliament and of the Council of 27 April 2016 on the protection of natural persons with regard to the processing of personal data and on the free movement of such data, and repealing Directive 95/46/EC (General Data Protection Regulation) https://eur-lex.europa.eu/legalcontent/EN/TXT/HTML/?uri=CELEX:32016R0679\&from=HU
} 
with up-to-date accuracy, and stored in a form which permits identification of data subjects for no longer than is necessary for the purposes for which the personal data are processed. When setting up a central database, it would seem inevitable to regulate the mandates and technical requirements in legislation in order to enforce these principles on the one hand, and to ensure the lawfulness of data processing on the other..$^{33}$ In order to ensure that data already processed are used only to the extent and in the form necessary, technological solutions may be required to ensure that the output information cannot be decrypted by users in respect of the data subjects. In this context, a possible solution could be to have the data controller itself perform the necessary operations on the input data according to the operational principle of the valuation, based on a central methodology, and only deliver the final result to the end users. Another solution that seems to be applicable is that the data controller distorts the outgoing data (e.g. in terms of geographic data) to such an extent that it allows for the carrying out of valuations but not for the identification of the property and the related personal data.

\subsection{Recommended structure of the central valuation database}

The set of required input data would be provided by specified data providers, and in the future it would be possible to extend the scope of specified data providers and possibly to provide optional data. In the case of the most important available data sets agreed with the data providers, it should be specified according to which set of rules they are updated and what ensures their reliability. In addition, the minimum amount of information per property on the basis of which disclosure can take place should be also specified.

It is advisable to involve a third party other than the data providers and data users in the management of the database; this party should have experience in database management and client relations and be able to coordinate client interests. This could be an existing database manager or a new entity set up specifically to manage this database. To ensure that the data are included in the database, a uniform definition system should be created, applicable to all data providers and covering all relevant data sets. To make the database operational, a number of technical details need to be elaborated. These include the development of custom templates for each type of information source, a common logical order for data management to resolve inconsistencies, mechanisms for data transfers and a data rectification scheme.

Based on our proposal, the use of the data would consist of an initial phase and a continuous expansion phase, and therefore the central database should be set up in such a way that subsequent expansions require as little modification as possible.

\footnotetext{
${ }^{33}$ In the absence of legislative action, the consent of the data subjects may be sufficient to populate the database, but it will take much longer to achieve the volume of data needed to make it work.
} 
Communication channels to the database should in most cases be able to provide two-way communication, but for some actors it may be required to send only inputs.

In our view, there are two necessary sub-processes for the database to work: the data provision process and the data request process. The timeliness of data provision is determined by the nature of the database: as we propose to create a stand-alone database, the data should be provided as soon as possible after the data is entered/changed, despite that it can only be taken into account when the next transaction price is recorded. The inclusion of data may, in addition to their processing, imply the need to delete previous data if a previously recorded data is modified and a new transaction price is recorded. In addition, it is necessary that data are only extracted from the database if the minimum set of data necessary to carry out the valuations is available. An important safeguard is that, although individual properties in the database must remain identifiable (even if based on distorted, anonymised identifiers), no parameter suitable for the identification of the property should be included in the output data (Figure 10).

\section{Figure 10}

A possible operational model for data processing

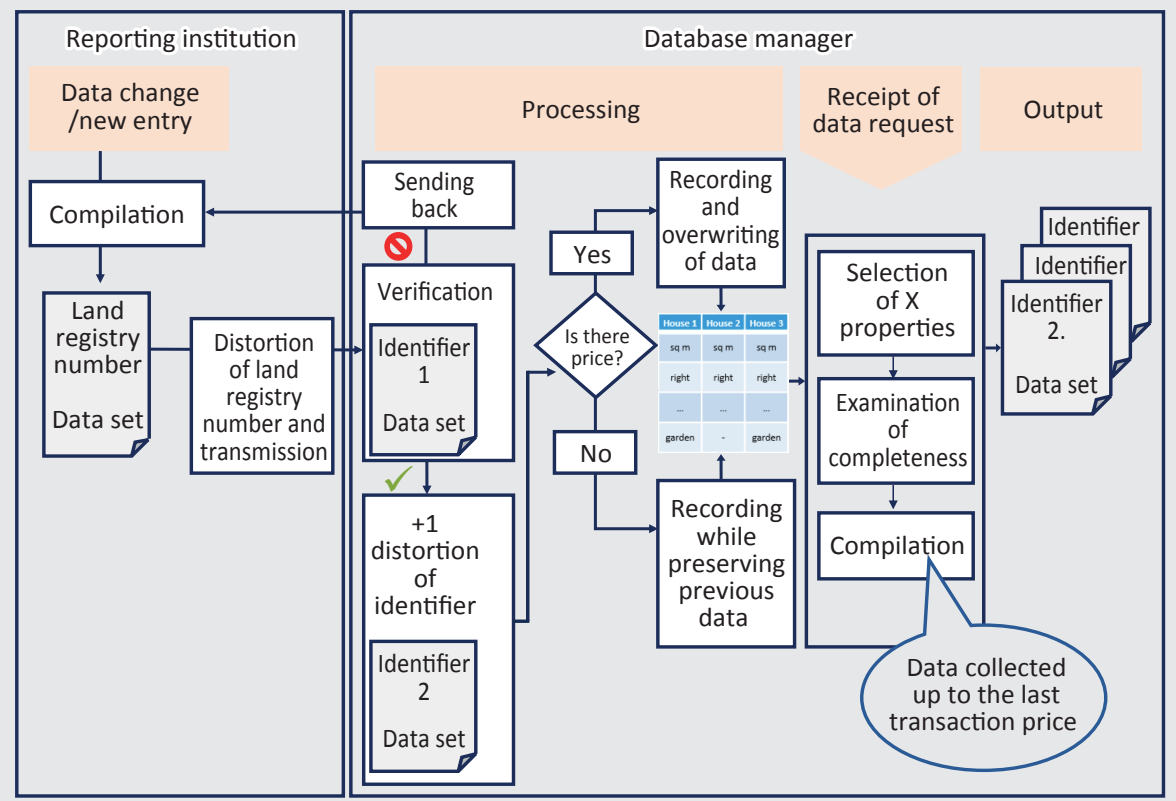


Care must be taken to ensure that the operation model does not create a competitive advantage or disadvantage for any actor in the sector, simply because of the regulatory activity, by using solutions that are not available to all institutions or that would be difficult or costly to implement. The development and improvement of valuation models using a wide range of available data may require significant resources, and regulators will need to consider which of the possible options are the most effective ways to exploit the potential of the new database. In our view, there are basically two models for bank data requests:

1. Centralised methodology: in this case, data requesters only submit a request for the result of the valuation and the database runs a common methodology using its stored data, based on legal and regulatory requirements. The advantage of the solution is that it reduces the risks to the accuracy of the valuation, there are no direct development costs for the institutions using the service, and the conditions for use are therefore equal in this respect. However, institutions that have already developed advanced valuation methodologies but can no longer use them could be at a disadvantage. Moreover, it can also slow down the innovation of models and the incorporation of new model developments.

2. Use of specific methodology: in this case, each institution can submit a unique request for data to the database, while the valuation is carried out according to a unique methodology. The procedure can have a risk-mitigating effect at the banking system level through diversification and can provide a significant incentive for bank development, but it can also be detrimental to smaller institutions. Where institutional models are used, the regulator should establish the requirement for regular quality checks, the necessary compliance criteria and back-testing requirements to ensure that the specificity of the models does not lead to outliers.

\subsection{Benefits, risks, challenges}

For actors in the real estate segments, particularly those in the financial markets, there are many benefits to be gained from the creation of a continuously accessible, comprehensive and reliable data set, in line with digitalisation efforts, and from ensuring the non-discriminatory retrieval of stored real estate data. In their responses to the MNB's 2021 questionnaire, Hungarian institutions stressed that they fundamentally expect the data to be up-to-date, of high quality, standardised and synchronised, and to eliminate uncertain data and extreme values.

By creating a central database, individual institutions can free up significant financial, technological and human resources, as long as they do not necessarily have to build their own database, maintain it regularly and adapt it to the changing infrastructure and regulatory environment. These cost savings can be used for other improvements, thereby further increasing competition between financial 
institutions. On the other hand, a central database can make the valuation processes automated, faster and more reliable, providing institutions with a larger database and less uncertainty in the process. The system clearly supports the reduction of inconsistencies, which will ultimately be felt by the clients of the actors in the sector. However, exposure to database centralisation carries also risks if the database controller cannot react quickly enough to market events, its size makes existing infrastructures difficult to shape, and thus any upgrades and modifications thereof can be costly. The accuracy of data is also critical in such a complex, easily accessible infrastructure, given the systemic problems that can arise if information is incomplete, incorrect or out-dated.

To minimise inconsistencies and data quality issues, it may also be useful for the new database to use already established channels, so that the costs of development can be kept low for both public and market operators. The infrastructure already developed and tested has an added value not only in terms of system maintenance costs, but also in terms of easier database expansion and easier contribution of new data streams, if IT systems only need to be fine-tuned. However, in the initial period, it should also be taken into account that smaller actors may have difficulties in adapting their systems to access the data. They may therefore find it challenging to use a wider range of data, however, these differences could soon disappear with the reallocation of freed-up resources mentioned earlier.

The biggest practical challenge in setting up a central database is probably the "initial upload" at the time of creation. If sufficient data are not available initially, the development of a central database may be stalled and may generate disinterest from the relevant market. The accuracy and reliability of the valuation, if the right methods are used, depends largely on the suitability of the data used and the proper construction of the database. One of the main sources of error in the valuation results produced by the statistical methods used, disregarding the deliberate manipulation of any element of the process, can be the database used, for example, errors of individual database elements, inappropriate linking of elements, too little data or an unrepresentative data set. Accordingly, the central database should be able to integrate incoming data that have been organised by "third party" databases according to a different methodology, or it should be able to match similar or identical data (e.g. in the case of linking land registry records with NTCA data).

Operation of the database on which the statistical valuation is based is inconceivable without an appropriate legal framework. In our view, the "initial upload" with respect to a property database with sufficient data quality and quantity, as well as its subsequent operation, can only be achieved on the basis of legal authorisation. As regards the range of potential data providers, it can be seen that their operations are governed by different legislation, the processing of personal data held by them 
is typically governed by sectoral laws, while the transfer of such data to third parties, in particular to the central database to be established, requires further amendments. With regard to the database controller, it is essential for the National Assembly to stipulate by law from whom it receives the data, for what purpose, for how long it may process such data and, where appropriate, to whom it may disclose such data. In our view, one central issue in the design of the data query model is the provision of data in anonymised form, which ensures that the problem of personal data processing does not arise for institutional users when applying the statistical model.

The acceptance and reliability of the system, as well as its legal framework, can have a major impact on the uptake of the scheme by actors. Market participants that have already built up their own large databases can only be voluntarily steered towards the need for the operation of a central database if these necessary preconditions are met. Owing to the geographical location of real estate, the potential number of loan transactions suitable for statistical valuation may be more limited if only a proprietary database is used, due to the different size and geographical presence of institutions (see Figures 4 and 5), but access to a central database would significantly increase the potential for use. An additional incentive can be provided by making data available in the system that would be difficult or impossible to access without joining the system. Participation in and reporting to the central database would increase the efficiency of the relevant actors, opening up potential new markets for them. By joining, the database-building real estate agents will be able to price the offered properties more accurately in their operations, thus enabling them to carry out more transactions per unit of time and indirectly influence the turnover rate of the domestic housing stock. Valuers should also be interested in entering, as they can also enter the statistical valuation market, in addition to the on-site inspection market. Under the EBA Guidelines, there will still be no way to fully circumvent valuers even in the case of statistical valuation (see Section 3.1), and it will be in their vital interest to establish and operate a central model if they have intention to follow market trends.

In determining the costs of developing and maintaining the system, account should also be taken of the essential purpose of the database, which is to ensure that all relevant operators can access the database and that their access to it brings clear benefits. Pricing must therefore necessarily reflect the extent to which each acceding party uses the database infrastructure. At the same time, during the set up and even during the subsequent expansion of the system, it is possible to envisage scenarios in which the participating organisations could contribute their own data assets to the development and maintenance of the system, thus benefiting from reduced costs depending on the extent and quality of these data assets, and could be interested in the greatest possible and most accurate transfer of and access to the data. 


\section{Conclusion}

The valuation of real estate collateral, like many other banking processes, is undergoing a major transformation. Instead of traditional valuations based on onsite inspections, the use of statistical valuation methods is becoming increasingly common internationally and expectedly also in Hungary. The legal conditions for this have been created by changes in European and Hungarian legislation over the past year, but in the longer term further changes are likely to be needed to make the method more widespread.

According to the views of domestic banks, statistical valuation methods are also expected to become increasingly important in various banking processes. However, for their functioning and the accuracy of the resulting value estimates, it is not sufficient to provide a legal framework. Data that are sufficiently detailed, accurate and regularly monitored are needed to ensure that they can be used effectively. The current databases on Hungarian real estate are highly fragmented and often limited in access, making it very difficult for market participants to access the quality and quantity of data they need, especially for smaller institutions or those with a shorter history, which weakens competition between actors. Therefore, by way of harmonising the existing separate databases, we propose to create a central database that provides a uniform, up-to-date set of data. A significant part of the data concerning real estate is recorded by various public bodies, which means that the management and use of the existing public data assets is of particular importance and can support the efficient functioning and competitiveness of the national economy in a number of processes. The creation of the National Data Assets Agency is a step in this direction, but the need for a flexible and open attitude on the part of public operators to manage data assets and to take the necessary steps in a timely manner remains a key priority. Such a database would help to create a level playing field in the market and would be able to serve data needs in an automated, cost-effective, fast and reliable manner. A central system reduces the chance of inconsistencies between data, and the integration of new types of data can be also simplified, without requiring additional IT development steps by each user. Banks would be able to produce valuations for their lending processes more accurately and faster, and could also rely on central data to improve other internal processes, whether it is product development or workout processes. In addition, there can be significant time and cost savings for borrowers by not having to do on-site inspections. We estimate that it would be possible to carry out statistical valuations for around 20,000-30,000 clients per year. With a 50-per cent reduction in the on-site valuation fee of HUF 30,000 due to the new method, as expected by banks, this could result in direct savings of up to HUF 300-450 million per year for mortgage loan borrowers, which could be complemented by a better client experience from faster loan approvals and lower shoe-leather costs. 
Certainly, such a database also poses challenges, such as the need to react quickly to market developments, or the need to keep data up-to-date and correct data errors as quickly as possible. Regulators and the system operator both need to be prepared for such challenges.

Overall, we believe that a central database would greatly facilitate the future use of statistical valuation methods as a key tool in the valuation of real estate collateral. This would help create the optimal utilisation of the existing domestic data on real estate, to kick-start the data economy, further spread the digitalisation already underway in banking processes, strengthen banking competition, speed up transactions and to reduce costs for both market actors and clients.

\section{References}

Aczél, Á. - Banai, Á. - Borsos, A. - Dancsik, B. (2016): Identifying the determinants of housing loan margins in the Hungarian banking system. Financial and Economic Review, 15(4): 5-44. https://en-hitelintezetiszemle.mnb.hu/letoltes/akos-aczel-adam-banai-andrasborsos-balint-dancsik.pdf

Béres, A.D. - Tringer, Zs. (2020): Ingatlanértékbecslés „otthonról”: a banki hatékonyságnövelés új fejezete (Property valuation "from home": a new chapter in banking efficiency). Szakmai cikk (Special article), Magyar Nemzeti Bank. https://www.mnb.hu/letoltes/beresalexandra-tringer-zsofia-ingatlanbecsles-otthonrol.pdf

Békés, G. - Horváth, Á. - Sápi, Z. (2016): Lakóingatlan-árak és települési különbségek (Differences between residential property prices and settlements). MT-DP - 2016/21, Magyar Tudományos Akadémia Közgazdaság- és Regionális Tudományi Kutatóközpont Közgazdaságtudományi Intézet (Institute of Economics, Centre for Economic and Regional Studies of the Hungarian Academy of Science), Budapest. http://www.econ.core.hu/file/ download/mtdp/MTDP1621.pdf

Dippong, M. - Harnos, L. (2008): Speciális ingatlanok értékelése (Evaluation of Special Properties). Distance learning note, Nyugat-Magyarországi Egyetem (University of West Hungary), Faculty of Geoinformatics, Székesfehérvár. http://docplayer.hu/16122724Specialis-ingatlanok-ertekelese.html. Downloaded: 26 October 2021.

EAA (2019): European Standards for Statistical Valuation Methods for Residential Properties 2nd edition. European AVM Alliance. https://www.europeanavmalliance.org/avmstandards.html?file=files/eaa/Downloads/EAA_Standards_2nd_Edition.pdf\&cid=156. Downloaded: 30 April 2020.

Eurostat (2013): Handbook on Residential Property Prices Indices (RPPIs). https://doi. org $/ 10.2785 / 34007$ 
Freixas, X. - Laeven, L. - Peydró, J.-L. (2015): Systemic Risk, Crises, and Macroprudential Regulation, The MIT Press. https://doi.org/10.7551/mitpress/9780262028691.001.0001

Horváth, Á. - Imre, B. - Sápi, Z. (2016): The International Practice of Statistical Property Valuation Methods and the Possibilities of Introducing Automated Valuation Models in Hungary. Financial and Economic Review, 15(4): 45-64. https://en-hitelintezetiszemle. $\mathrm{mnb}$.hu/letoltes/aron-horvath-blanka-imre-zoltan-sapi.pdf

IAAO (2018): Standard on Automated Valuation Models (AVMs). International Association of Assessing Officers. https://www.iaao.org/media/standards/AVM_STANDARD_2018.pdf. Downloaded: 13 April 2021.

MNB (2017): Financial savings of households based on micro- and macro statistical data. Magyar Nemzeti Bank. https://www.mnb.hu/letoltes/ha-ztarta-sok-eng.PDF

MNB (2019): Competitiveness Programme in 330 points. Magyar Nemzeti Bank. https:// www.mnb.hu/letoltes/competitiveness-programme-in-330-points.pdf

MNB (2021a): Housing Market Report, May 2021. Magyar Nemzeti Bank. https://www.mnb. hu/letoltes/lakaspiaci-jelentes-2021-majus-en.pdf

MNB (2021b): Financial Stability Report, June 2021. Magyar Nemzeti Bank. https://www. $\mathrm{mnb}$.hu/letoltes/financial-stability-report-2021-june.pdf

MSCl (2019): Private Real Estate: Valuation and Sale Price Comparison 2019. MSCI Research Report, June. https://www.msci.com/www/research-paper/private-real-estatevaluations/01032853837

RICS (2017): The Future of Valuations - The relevance of real estate valuations for institutional investors and banks - views from a European expert group. RICS Insight Paper 2017/11, Royal Institution of Chartered Surveyors. https://www.rics.org/globalassets/ricswebsite/media/knowledge/research/insights/future-of-valuations-insights-paper-rics.pdf. Downloaded: 27 April 2020.

Stan, L. (2015): De la idee la BIG - ANEVAR. Valoarea oriunde este ea, 2015(6): 14-17. https://www.anevar.ro/images/documente/revista-valoarea-oriunde-este-ea-nr-06.pdf. Downloaded: 6 October 2021.

Wolters, J. (2002): Property valuation and taxation in Denmark. The Danish Association of Chartered Surveyors, Copenhagen. http://www.andywightman.com/docs/danish_ propertytax.pdf. Downloaded: 6 October 2021. 